\title{
Peningkatan Keterampilan Membaca Permulaan pada Pembelajaran Tematik dengan Metode Global Kelas 1 SDN Kajen 02
}

\author{
Gagas Pamulyo Aji, Sugeng Riyanto \\ PGSD Universitas Ahmad Dahlan \\ Pos-el: gagaspamulyoaji@gmail.com
}

\begin{abstract}
This study aims to determine the improvement of early reading skills in students in using global methods for grade 1 Kajen Negri Elementary School 02. Background This study is that there are still many students who cannot read. Another condition is that many teachers present learning by emphasizing material that only focuses on thematic books and does not yet utilize contextual approaches.

This research was conducted using two cycles. Each cycle consists of two meetings. The study subjects numbered 23 students, including 13 male students and 10 female students. The object of this research is the application of initial reading skills in the thematic learning subtheme 1 (me and a new friend). Data collection techniques in the form of tests, observations, documentation and interviews. Data analysis uses qualitative and quantitative analysis.

The results of this study indicate that the application of global methods can improve initial reading skills in students. Students who get the value of complete reading skills in pre-cycle as much as $48 \%$ (11 students). In the first cycle the average value of students who completed 67, with a percentage of completeness of 61\% (14 students). In the second cycle the average value of students who completed was 76.3 with a percentage of completeness $78 \%$ (18 students). It can be concluded that the global method can improve initial reading skills, thus the researcher's suggestions for teachers should apply the global method in beginning reading skills.
\end{abstract}

Keyword: Global Method, Beginning Reading Skills, Indonesian

\begin{abstract}
ABSTRAK
Penelitian ini bertujuan untuk mengetahui peningkatan ketrampilan membaca permulaan pada peserta didik dalam menggunakan metode global bagi kelas $1 \mathrm{SD}$ Negri Kajen 02. Penelitian ini dilatarbelakangi bahwa masih banyak peserta didik yang belum bisa membaca dan guru menyajikan pembelajaran dengan menekankan materi yang hanya berfokus pada buku tematik, dan juga belum memanfaatkan pendekatan kontekstual yang mempergunakan metode dalam pembelajaran kurang maksimal.

Penelitian ini dilakukan dengan menggunakan II siklus, dan setiap siklus terdiri dari dua pertemuan. Subjek penelitian berjumlah 23 peserta didik, diantaranya 13 peserta didik laki-laki dan 10 peserta didik perempuan. Objek penelitian ini adalah penerapan keterampilan membaca permulaan pada pembelajaran tematik subtema 1
\end{abstract}


(aku dan teman baru). Teknik pengumpulan data berupa tes, observasi, dokumentasi dan wawancara. Analisis data yang digunakan yaitu analisis kualitatif dan kuantitatif.

Hasil penelitian ini menunjukkan bahwa penerapan metode global dapat meningkatkan ketrampilan membaca permulaan pada peserta didik. Peserta didik yang mendapatkan nilai ketrampilan membaca yang tuntas pada pra siklus sebanyak $48 \%$ (11 peserta didik). Pada siklus I nilai rata-rata peserta didik yang tuntas yaitu 67 dengan persentase ketuntasan sebanyak 61\% (14 peserta didik), sedangkan pada siklus II nilai rata-rata peserta didik yang tuntas yaitu 76,3 dengan persentase ketuntasan 78\% (18 peserta didik). Dapat disimpulkan bahwa metode global dapat meningkatkan ketrampilan membaca permulaan, dengan demikian saran peneliti untuk guru hendaknya menerapkan metode global dalam ketrampilan membaca permulaan.

Kata kunci: Metode Global, Ketrampilan Membaca Permulaan, Bahasa Indonesia.

\section{PENDAHULUAN}

Pendidikan adalah sebuah usaha yang dilakukan secara sadar dengan tujuan untuk menggali dan mengembangkan potensi yang ada pada diri dengan disesuaikan pada budaya masyarakat (Ihsan, 2013:2). Pembelajaran tematik menurut Majid (2014:80) adalah salah satu model pembelajaran terpadu (integrated instruction) yang merupakan suatu sistem pembelajaran yang memungkinkan siswa, baik secara idividu maupun secara kelompok aktif menggali dan menemukan konsep serta prinsip-prinsip keilmuan secara holistik, bermakna, dan otentik. Berdasarkan teori tersebut di simpulkan bahwa pembelajaran tematik yang menggabungkan dari beberapa mata pelajaran yang membuat peserta didik menjadi objek yang utama.

Membaca merupakan suatu kegiatan yang melalui proses kognitif yang bertujuan untuk menemukan informasi yang terdapat pada tulisan (Dalman, 2017). Membaca adalah sebuah ketrampilan berbahasa yang di mana ketrampilan berbahasa merupakan suatu yang utama dalam menyampaikan apa yang ada dalam pikiran sehingga munculah sebuah perkataan.

Menurut (Supriasmoro, 2013:46) kesulitan membaca itu berupa: (1) kesalahan dalam mengidentifikasi bunyi huruf agar dapat berjalan dengan lancar ketika dalam membaca bersuara, (2) kebiasaan arah membaca yang salah dimana peserta didik biasanya membaca dengan berbagai arah yaitu dimana peserta didik memulai membaca dengan awal kata yang menarik, (3) kelemahan kemampuan pemahaman,dimana peserta didik belum paham dari isi bacaan teks namun bisa memahami dari menggunnakan metode gambar, (4) kesulitan menyesuaikan diri dengan jenis bacaan, jenis bacaan anak yang sesuai adalah dengan karakter buku. Untuk karakter buku memiliki 3 macam yaitu, gambar buku, buku gambar panjang, ilusttrasi buku, (5) kelemahan dalam hal kecepatan dalam membaca. Kelemahan dalam hal membaca biasanya terjadi ketika anak usia yang hendak masuk ke sekolah dasar dimana peserta didik seharusya sudah mulai bisa mengeja membaca dengan benar. Berdasarkan 
kesulitan membaca tersebut maka dapat diatasi dengan salah satunya menerapkan ketrampilan membaca permulaan.

Keterampilan membaca permulaan hendaknya segera dikuasai oleh siswa sejak awal di SD. Siswa yang tidak memiliki keterampilan membaca permulaan dengan baik akan mengalami kesulitan dalam memahami informasi informasi berbagai ilmu pengetahuan yang disajikan dalam buku pelajaran, bahan-bahan pembelajaran dan sumber-sumber pembelajaran tertulis. Selain itu anak yang tidak dapat menguasai keterampilan membaca permulaan dengan baik kemajuan belajarnya juga lamban dibandingkan dengan teman-temannya yang tidak mengalami kesulitan belajar.

Berdasarkan observasi di SD Negeri Kajen 02 sebanyak 2 kali yang dilakukan pada tanggal 12 Juli 2018 dan 28 Juli 2018 maka dapat disimpulkan bahwa masih banyaknya peserta didik yang belum bisa membaca dan guru menyajikan pembelajaran dengan menekankan materi yang hanya berfokus pada buku tematik, dan juga belum memanfaatkan pendekatan kontekstual yang mempergunakan metode dalam pembelajaran kurang maksimal. Sehingga peserta didik kurang berkomunikasi dengan peserta didik lainya serta banyaknya peserta didik yang belum lancar dalam membaca. Pada observasi yang dilakukan dengan mewawancarai guru di sekolah tersebut beliau menyampaikan bahwa beberapa peserta didik masih kesulitan membaca dengan menggabungkan beberapa kalimat. Dengan adanya masalah peneliti ingin meneliti kesulitan membaca dengan menggunakan metode global. Adanya penelitian ini bertujuan untuk pembelajaran menjadi mudah di terima dan siswa dapat berkomunikasi dengan menggunakan teks bacaan secara aktif sehingga pembelajaran tidak membosankan. Dalam hal ini penulis menciptakan suasana belajar yang menyenangkan melaui penerapan metode global.

Menurut Wahyuning (2015:59) Metode global adalah metode yang melihat segala sesuatu sebagai keseluruhan, dimana metode global mengajarakan dari tingkatan berbagai teks dan menggunakan gambar supaya peserta didik dapat memahami dengan mudah isi bacaan yang ada dalam teks tersebut. Berdasarkan teori tersebut metode global adalah metode yang menarik karena metode tersebut disertai dengan gambar yang sesuai pembahasan. Pada metode global diajarkan mulai dengan melihat gambar setelah itu peserta didik dapat menguraikan kalimat dengan kata-kata kemudian katakata tersebut dirubah menjadi suku kata lalu suku kata tersebut di rubah menjadi hurufhuruf. Kelebihan metode global adalah peserta didik cepat memahami dalam membaca karena dengan bantuan gambar yang membuat peserta didik kelas 1 sekolah dasar menjadi lebih mudah dalam membaca yang memiliki kesulitan membaca karena dengan menggunakan metode global peserta didik mengerti kata dengan menggunakn metode gambar.

Berdasarkan pemaparan tersebut maka penulis akan melakukan penelitian yang berjudul "Peningkatan Keterampilan Membaca Permulaan pada Pembelajaran Tematik Dengan Metode Global Kelas 1 SD Negri Kajen 02”. 


\section{METODE PENELITIAN}

Penelitian ini dilaksanakan di SD Negri Kajen 02 Kabupaten Tegal. Jenis penelitian ini adalah penelitian tindakan kelas yang bertujuan untuk meningkatkan kualitas proses dan hasil pembelajaran di kelas, serta dapat menyelesaikan permasalahan pembelajaran di kelas yang dilakukan secara bersiklus. Subjek dalam penelitian ini meliputi guru dan peserta didik kelas 1 SD Negri Kajen 02. Jumlah peserta didik kelas 1 sebanyak 23, yang terdiri atas 13 peserta didik laki-laki dan 10 peserta didik perempuan, sedangkan peneliti bertugas sebagai pengamat atau observer. Langkah-langkah penelitian tindakan kelas dibuat lebih efektif dan efisien guna meningkatkan ketrampilan membaca permulaan dengan menggunakan metode global. Pengumpulan data dalam penelitian ini meliputi tes, observasi, wawancara dan dokumentasi. Uji validitas yang digunakan dalam penelitian ini adalah validitas konstruk. Validitas ini berkenaan dengan struktur yang akan di ukur. Pengujian validitas konstruk pada penelitian ini dibantu dengan uji validitas instrument oleh ahli yaitu dosen. Dari hasil validasi dengan dosen dapat diperole kesimpulan bahwa lembar instrument dapat digunakan sebagai observasi dan pedoman untuk melaksanakan penelitian.

\section{HASIL DAN PEMBAHASAN}

Penelitian tindakan kelas ini dilakukukan di kelas 1 SD Negeri Kajen 02 yang berlokasi di Jalan Narawisan, Rt 10 Rw 4, Kajen, Talang, Tegal, Jawa Tengah 52193. Jumlah peserta didik terdiri dari 23 peserta didik dimana 13 laki-laki dan 10 perempuan. Pelaksanaan observasi terlebih dahulu dilakukan sebelum penelitian, yang bertujuan untuk mengetahui keadaan yang nyata dilapangan.

Dibawah ini merupakan hasil pre test, siklus I dan siklus II peserta didik kelas 1 sebagai berikut berdasarkan nilai:

Tabel 1.

Hasil Pre Test, Siklus I dan Siklus II

\begin{tabular}{|c|c|c|c|c|}
\hline \multirow{2}{*}{ No. } & \multirow{2}{*}{ Nama } & \multicolumn{3}{|c|}{ Nilai } \\
\cline { 3 - 5 } & & Pre test & Siklus I & Siklus II \\
\hline 1 & ARF & 75 & 85 & 90 \\
\hline 2 & AR & 60 & 70 & 75 \\
\hline 3 & AGR & 75 & 80 & 85 \\
\hline 4 & ADT & 50 & 55 & 70 \\
\hline 5 & AH & 70 & 75 & 85 \\
\hline 6 & AHU & 55 & 60 & 70 \\
\hline 7 & ASP & 80 & 95 & 100 \\
\hline 8 & AK & 65 & 70 & 85 \\
\hline 9 & ARK & 70 & 75 & 85 \\
\hline 10 & DR & 50 & 55 & 60 \\
\hline 11 & DBR & 80 & 90 & 95 \\
\hline
\end{tabular}




\begin{tabular}{|l|c|c|c|c|}
\hline 12 & INA & 75 & 80 & 85 \\
\hline 13 & MLM & 30 & 30 & 50 \\
\hline 14 & MAM & 70 & 75 & 85 \\
\hline 15 & MSR & 40 & 45 & 55 \\
\hline 16 & MFI & 60 & 70 & 75 \\
\hline 17 & MFN & 55 & 60 & 75 \\
\hline 18 & MI & 35 & 40 & 55 \\
\hline 19 & MFM & 60 & 75 & 85 \\
\hline 20 & MKG & 45 & 50 & 75 \\
\hline 21 & NM & 70 & 75 & 85 \\
\hline 22 & RA & 40 & 45 & 60 \\
\hline 23 & UH & 75 & 80 & 85 \\
\hline
\end{tabular}

Berdasarkan hasil pre test, siklus I dan siklus II terjadi peningkatan dan sudah memenuhi target yang ditetapkan oleh penulis dalam ketrampilan membaca permulaan peserta didik. Berikut dapat disajikan dalam gambar grafik:

Grafik Rekapitulasi Hasil Nilai Pre test, Siklus I dan Siklus II

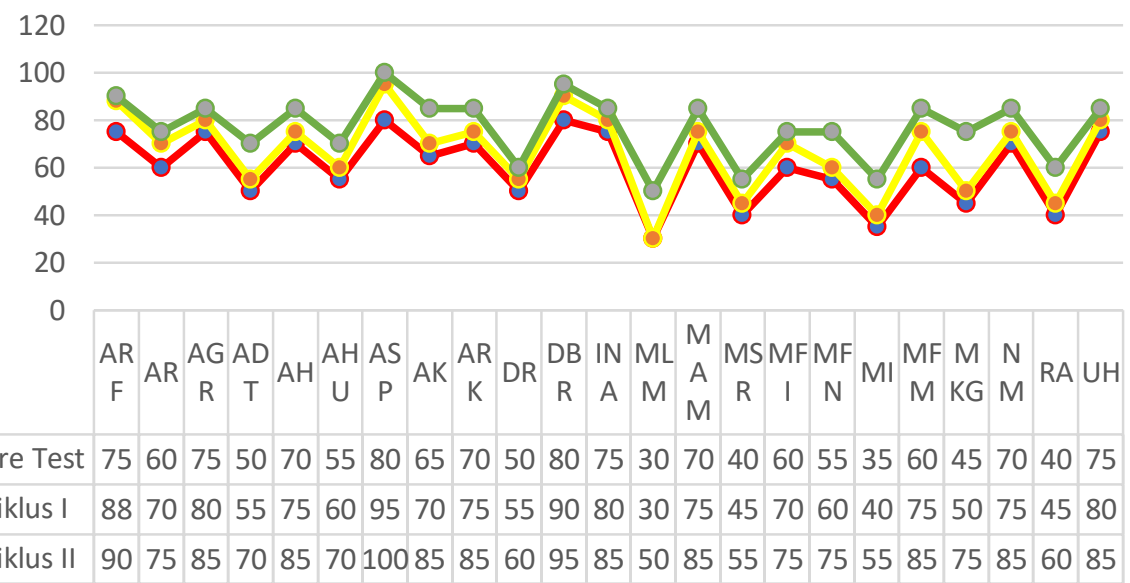

Gambar 1.

Berdasarkan gambar 1 tersebut dapat dilihat hasil ketrampilan membaca peserta didik pada tiap siklus. Peserta didik yang mendapatkan nilai ketrampilan membaca yang tuntas pada pra siklus sebanyak 48\% (11 peserta didik). Pada siklus I nilai ratarata peserta didik yang tuntas yaitu 67 dengan persentase ketuntasan sebanyak 61\% (14 peserta didik), sedangkan pada siklus II nilai rata-rata peserta didik yang tuntas yaitu 76,3 dengan persentase ketuntasan 78\% (18 peserta didik). Secara keseluruhan penelitian tindakan kelas yang telah dilakukan untuk meningkatkan ketrampilan membaca permulaan telah mengalam peningkatan sesuai indikator keberhasilan yang telah ditetapkan penulis. 


\section{SIMPULAN}

Peningkatan hasil keterampilan membaca permulaan dapat dilihat berdasarkan analisis data peningkatan nilai keterampilan membaca permulaan peserta didik Hasil tes keterampilan membaca permulaan peserta didik pra tindakan adalah 7 peserta didik mencapai nilai diatas KKM yaitu 65 dan 16 peserta didik belum mencapai nilai KKM. Presentase ketuntasan $30 \%$. Pada siklus I, ada 14 peserta didik yang mencapai nilai KKM dan 9 peserta yang belum mencapai nilai KKM. Nilai rata-rata kelas adalah 67 dan presentase ketuntasan $61 \%$. Pada siklus II, terjadi peningkatan ketuntasan belajar yang baik yaitu ada 18 peserta didik yang mencapai nilai KKM dan 5 peserta didik yang belum mencapai KKM. Nilai ratarata kelas adalah 76,3 dan presentase ketuntasan $78 \%$. Hasil penelitian ini telah membuktikan bahwa metode global dapat meningkatkan keterampilan membaca permulaan pada siswa kelas I SD Negeri Kajen 02, Kecamatan Tegal, Kabupaten Tegal.

\section{DAFTAR PUSTAKA}

Dalman. (2017). Ketrampilan Membaca. Jakarta: PT Raja Grafindo Persada.

Ihsan, F. (2013). Dasar-Dasar Kependidikan. Jakarta: PT Rineka Cipta.

Majid, A. (2014). Pembelajaran Tematik Terpadu. Bandung: PT Remaja Rosdakarya.

Supriasmoro. (2013). Menangani Anak Kesulitan Membaca. Nosi, 1, 46.

Wahyuning, D. (2015). Penerapan Metode Membaca Global Untuk Meningkatkan Kemampuan Membaca Mata Pelajaranbahasa Indonesia Pada Siswa Kelas I SDN 01 Semboro Kabupaten Jember. Pancaran, 4(4), 59-68. 